\title{
Water, nitrogen and energy use efficiency in major crops production systems in Iran
}

\begin{abstract}
The aims of this study were to determine water, nitrogen and energy use efficiency in major crop production of Kermanshah province, western of Iran such as wheat, corn, alfalfa and sugar beet. Data was collected applying questionnaires via face to face interviews with 200 farmers (50 farmers for each crop) in 2014. Results showed total nitrogen fertilizer input in wheat, corn, alfalfa and sugar beet were $358.7,580.57$, 200 and $653.91 \mathrm{~kg} / \mathrm{ha}$, respectively. In the other hand, total irrigated water in wheat, corn, alfalfa and sugar beet was 5850, 8669.2, 6563.7 and $11880 \mathrm{~m} 3 /$ ha, respectively. Accordingly, nitrogen use efficiency (NUE) was $15.81,19.51,67.55$ and $99.71 \mathrm{~kg} / \mathrm{kg}$ for corn, wheat, alfalfa and sugar beet respectively. In this research water use efficiency (WUE) in wheat, corn, alfalfa and sugar beet was $1.20,1.06,2.06$ and $5.49 \mathrm{~m} 3 / \mathrm{ha}$ respectively. In this study total output and input energy were 60832.52 and $184150 \mathrm{Mj} /$ ha in wheat agroecosystems, 50485.42 and $134946 \mathrm{Mj} / \mathrm{ha}$ in corn agroecosystems, 49689.59 and $240072.7 \mathrm{Mj} / \mathrm{ha}$ in alfalfa agroecosystems and 49517.2 and $1095360 \mathrm{Mj} /$ ha in sugar beet agroecosystems. Energy use efficiency (EUE) was 2.67, 3.03, 4.83 and 22.12 in corn, wheat, alfalfa and sugar beet production, respectively. Hence, the highest amount of WUE, NUE and EUE were observed in sugar beet and then alfalfa and wheat respectively and lowest amounts were observed in corn agroecosystems.
\end{abstract}

Volume 2 Issue 3 - 2015

\author{
Mohammad Yousefi,' Mahmoud \\ Khoramivafa,' Ebrahim Zarei Shahamat ${ }^{2}$ \\ 'Department of Agronomy and Plant Breeding, Razi University, \\ Iran \\ ${ }^{2}$ Department of Agricultural Machinery Engineering, University \\ of Tabriz, Iran
}

\begin{abstract}
Correspondence: Mohammad Yousefi, Department of Agronomy and Plant Breeding, Campus of Agriculture and Natural Resources, Razi University, Kermanshah, Iran, Tel 989188376126, Email m.y6126@yahoo.com
\end{abstract}

Received: December 28, 2014 | Published: April 30, 2015

Keywords: major crop, nitrogen fertilizer, nitrogen use efficiency, water use efficiency, energy use efficiency

Abbreviations: NUE, nitrogen use efficiency; WUE, water use efficiency; EUE, energy use efficiency

\section{Introduction}

Kermanshah province is an important agricultural region in Iran. This province has a high crop growing potential. Wheat, corn, alfalfa and sugar beet cucumber are dominant products growing in this province. Resource use in agricultural production has become more intensive due to use of fossil fuel, chemical fertilizers, pesticides, machinery, irrigated water and electricity power to provide substantial increases in food production. ${ }^{1}$ However, more intensive Resource use has brought some important human health and environment problems so efficient use of inputs has become important in terms of sustainable agricultural production. Iran's chemical fertilizer consumption in agriculture systems has increased in recent years; therefore the associated problems have grown.

In agriculture, efficiency is the relationship between output and input calculated as a ratio (output/input) or as the slope of the functional relationship ( $\Delta$ output $/ \Delta$ input). ${ }^{2}$ Relevant outputs include crop production measured as total biomass, grain yield, or particular yield components such as oil, protein or kilocalories. Depending on the application, production can be expressed as mass $\left(\mathrm{kg} \mathrm{ha}^{-1}\right)$, energy $\left(\mathrm{MJ} \mathrm{ha}^{-1}\right)$ or monetary units $\left(\$ \mathrm{ha}^{-1}\right)$. Inputs include water, nutrients, radiation, fossil energy, labor and capital. Whereas the particular definition of efficiency used depends on the application and data availability, the multitude of possible combinations of outputs and inputs makes explicit definitions highly recommendable. Currently producers use more energy source such as chemical fertilizer and irrigated water to increase total output since there is no chance to expand the size of arable lands and producers do not have enough knowledge on more efficient energy inputs. The energy ratios in agricultural production are closely related with production techniques, quantity of inputs used by producers and yield level of crops along with environmental factors such as soil and climate. ${ }^{3}$ Therefore, there is a range of energy input and output relationships for the same crop depending on the region. Considerable research studies have been conducted on resource use in agriculture..$^{4-7}$ The main aims of this study were to determine nitrogen, water and energy use efficiency in major crop production systems such as wheat, corn, alfalfa and sugar beet of Kermanshah province, western of Iran.

\section{Materials and methods}

Kermanshah Province is located in western Iran (with $33^{\circ} 4^{\prime}$ and $35^{\circ} 17^{\prime} \mathrm{N}$ and $45^{\circ} 25^{\prime}$ and $48^{\circ} 6^{\prime} \mathrm{E}$ ). The long-term climate of the region is characterized by an annual average rainfall of $450 \mathrm{~mm}$, distributed mostly in winter and spring; the annual average temperature is $14.2^{\circ} \mathrm{C}$ with a monthly maximum of $27.6^{\circ} \mathrm{C}$ in July and a minimum of $2.2^{\circ} \mathrm{C}$ in January. ${ }^{8}$ In this study data was collected from wheat, corn, alfalfa and sugar beet production systems. Hence, farmers was selected based on randomly sample method and data were collected by using a faceto-face questionnaire. 200 questionnaires were completed in equal number (50 questionnaires) for each crops production systems.

The energy equivalents of inputs used in the crop production and output energy related to yield and biomass were estimated according to a study by Ghazvineh et al., ${ }^{1}$ Water use efficiency (WUE), nitrogen use efficiency (NUE) and energy use efficiency (EUE) were calculated 
according to the following equation $(1,2 \text { and } 3,)^{9,10}$

$\mathrm{EUE}=($ Output energy $[\mathrm{MJ} / \mathrm{ha}]) /($ Input energy[MJ/ha] $) \ldots(1)$

WUE $=($ Crop yield $[\mathrm{Kg} / \mathrm{ha}]) /($ Water used $[\mathrm{m} 3 / \mathrm{ha}]) \ldots(2)$

NUE $=($ Crop yield $[\mathrm{Kg} / \mathrm{ha}]) /($ Nitrogen used $[\mathrm{kg} / \mathrm{ha}]) \ldots(3)$

\section{Results and discussion}

\section{Water and nitrogen use efficiency}

Amounts of irrigation water and Nitrogen fertilizer consumed in major agroecosystems with to those yields of major crops production in Kermanshah providence are shown in Table 1. On the other hand total irrigated water in wheat, corn, alfalfa and sugar beet was 5850 , $8669.2,6563.7$ and $11880 \mathrm{~m}^{3} /$ ha, respectively. The maximum amounts of water and nitrogen fertilizers used were related to sugar beet agroecosystems. On the other hand, the highest yield $(65200 \mathrm{~kg} / \mathrm{ha})$ was related to this crop. It is not worthy that; the high amount of sugar beet yield is related to harvested root yield as component of economic yield of sugar beet agroecosystems. Amount of nitrogen fertilizer consumed in corn and sugar beet agroecosystems was about 1-2 times that of other agroecosystems (alfalfa and wheat). Total nitrogen fertilizer input in wheat, corn, alfalfa and sugar beet agroecosystems were $358.7,580.57,200$ and $653.91 \mathrm{~kg} / \mathrm{ha}$, respectively.

Accordingly this input and outputs (water, nitrogen and yield) water and nitrogen use efficiency in wheat, corn, alfalfa and Sugar beet production was calculated and are illustrated in Table 2 . The results showed that in wheat production agroecosystems was produced 19.51 and $1.20 \mathrm{~kg}$ of grain yield per kilogram of nitrogen fertilizer and $\mathrm{m}^{3}$ of water consumed by irrigation. These amounts were 15.81 and 1.06 $15.81 \mathrm{~kg}$ of grain by corn per kilogram of nitrogen fertilizer and $\mathrm{m} 3$ of water consumed by irrigation.

In alfalfa agroecosystems was produced 2.06 and $67.55 \mathrm{~kg}$ of forage yield per kilogram of nitrogen fertilizer and $\mathrm{m} 3$ of water consumed by irrigation. And also in sugar beet production tuber yield output per kilogram of used nitrogen fertilizer and $\mathrm{m}^{3}$ of water consumed by irrigation were 5.49 and $99.71 \mathrm{~kg}$.

\section{Energy analysis of major crops production systems}

Total input and output energy and energy use efficiency in wheat, corn, alfalfa and sugar beet are shown in Table 3. The results revealed that total energy input and output energy in wheat production systems were 60832.52 and $184150 \mathrm{MJ} / \mathrm{ha}$. Accordingly, energy use efficiency in wheat agroecosystems was 3.03. The highest share of input energy in this agroecosystems was related to electricity power, $\mathrm{N}$ fertilizer and diesel fuel with 36,18 and $13 \%$, respectively. ${ }^{9}$

In corn agroecosystems $50485.42 \mathrm{MJ} /$ ha of energy was used and $134946 \mathrm{MJ} / \mathrm{ha}$ of energy was produced. Yousefi et al., ${ }^{11}$ reported that highest share of total input energy in corn production systems were recorded for $\mathrm{N}$ fertilizer, electricity and diesel fuel with 35,25 and $20 \%$, respectively.

Table I Amounts of irrigated water, nitrogen use and yield of major crops in Kermanshah province

\begin{tabular}{llll}
\hline Crops & $\begin{array}{l}\text { Irrigated water } \\
\left(\mathbf{m}^{3} / \mathbf{h a}\right)\end{array}$ & Nitrogen fertilizer(Kg/ha) & $\begin{array}{l}\text { Yield }(\mathbf{k g} / \\
\mathbf{h a})\end{array}$ \\
\hline Wheat & 5850 & 358.7 & 7000 \\
Corn & 8669.2 & 580.57 & 9180 \\
alfalfa & 6563.7 & 200 & 13510 \\
Sugar Beet & 11880 & 653.91 & 65200 \\
\hline
\end{tabular}

Table 2 Amounts of water and nitrogen use efficiency of major crops in Kermanshah province

\begin{tabular}{lll}
\hline Crops & Water use efficiency (WUE) $\left(\mathbf{k g} / \mathbf{m}^{3}\right)$ & Nitrogen use efficiency (NUE) $\mathbf{( k g} / \mathbf{k g})$ \\
\hline Wheat & 1.2 & 19.51 \\
Corn & 1.06 & 15.81 \\
alfalfa & 2.06 & 67.55 \\
Sugar Beet & 5.49 & 99.71 \\
\hline
\end{tabular}

Table 3 Input and output energy along with energy use efficiency of major crops in Kermanshah

\begin{tabular}{llll}
\hline Crops & Input energy $(\mathbf{M J} / \mathbf{h a})$ & Output energy (MJ/ha) & Energy use efficiency (EUE) \\
\hline Wheat & 60832.52 & 184150 & 3.03 \\
Corn & 50485.42 & 134946 & 2.67 \\
alfalfa & 49689.59 & 240072.7 & 4.83 \\
Sugar Beet & 49517.2 & 1095360 & 22.12 \\
\hline
\end{tabular}




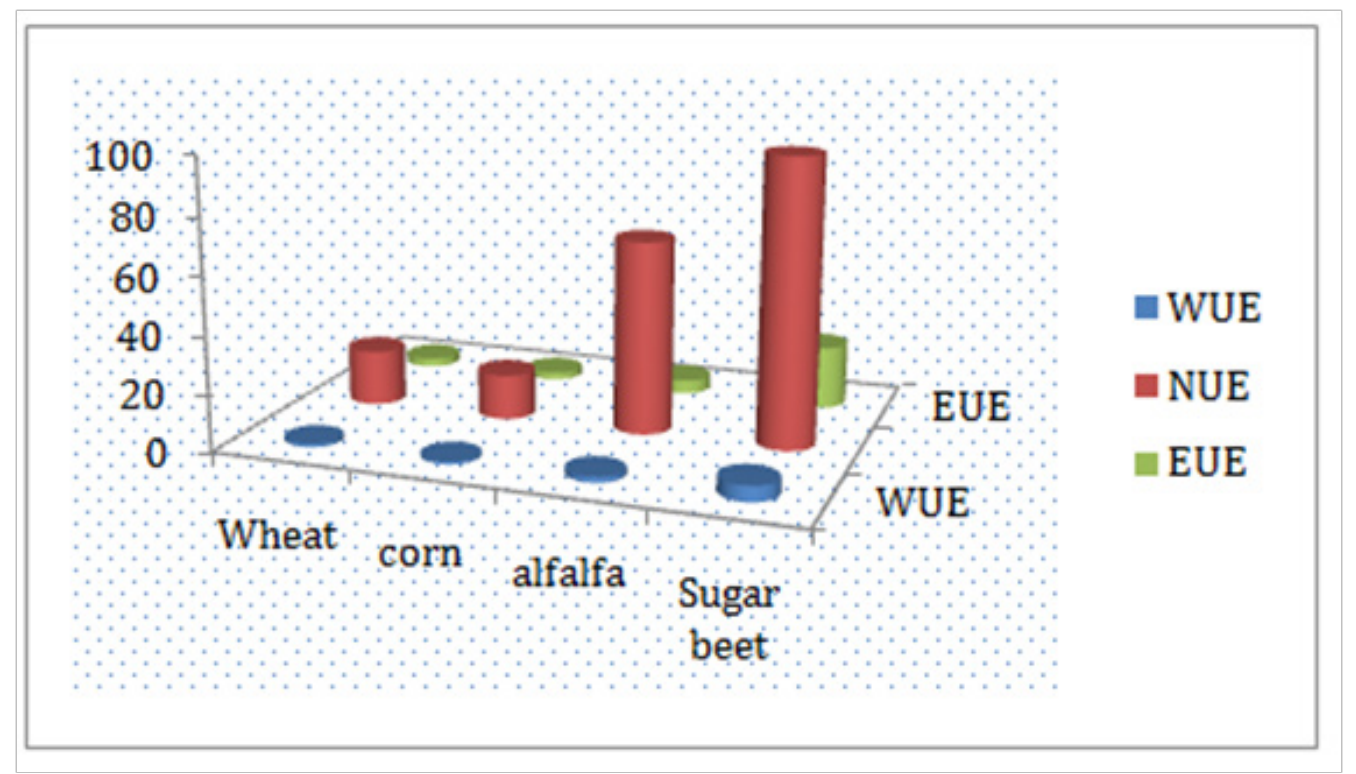

Figure I Amounts of resource use efficiency of major agroecosystems in Kermanshah province.

In alfalfa agroecosystems, results showed that total energy input and output were 49689.59 and $240072.7 \mathrm{MJ} / \mathrm{ha}$, respectively. The highest share of input energy was recorded for diesel fuels, electricity and $\mathrm{N}$ fertilizer respectively. ${ }^{10}$ The results also showed that energy use efficiency was 4.83 . Total input and output energy for sugar beet were 49517.20 and 1095360 $\mathrm{MJha}^{-1}$. $\mathrm{N}$ fertilizer used in sugar beet production systems was a high share with $27.90 \%$. Electricity energy used in sugar beet production systems ranked in the second place with $20 \%$ in the total energy input. The lowest shear of total energy was recorded for seed $(0.22 \%) .{ }^{12}$ Accordingly energy use efficiency for sugar beet productions was 22.12 .

In short, for evaluated agroecosystems in this region the highest amounts of water, nitrogen and energy use efficiency was observed by sugar beet production systems (Figure 1), that it was mostly due to the high tuber yield per unit area.

\section{Conclusion}

In this study, resource use efficiency such as irrigation water, nitrogen fertilizer and energy used of major crops production systems in Kermanshah province, western part of Iran has been investigated. Among the crops investigated, sugar beet had the highest resource use efficiency, then alfalfa, corn and in finally wheat. The higher water, nitrogen and energy use efficiency for sugar beet production indicated a higher yield per hectare from the other crops. Hence, more yields for a given input will lead to increased efficiency of agro ecosystem. Efficient use of energy is imperative for sustainability in food production systems. Therefore energy management in agroecosystems should be considered an important field in terms of efficient and sustainable use of energy.

\section{Acknowledgements}

None.

\section{Conflict of interest}

The author declares no conflict of interest.

\section{References}

1. Ghazvineh S, Yousefi M. Evaluation of consumed energy and greenhouse gas emission from agroecosystems in Kermanshah province. Tech J Engin \& App Sci. 2013;3(4):349-354.

2. Food and Agriculture Organization Statistic (FAOSTAT). Food and Agriculture Organization; 2010.

3. Yousefi M, Mahdavi DA. Evaluation of energy flow and indicators of chickpea under rainfed condition in Iran. International Journal of Farming and Allied Sciences. 2012;1(2):57-61.

4. Singh JM. On farm energy use pattern in different cropping systems in Haryana, India. Germany: Intent of Management, Sustainable Energy Systems and Management, Master of Science Thesis, Germany: University of Flensburg; 2002.

5. Kennedy S. Energy use in American agriculture. Sustainable Energy Term Paper; 2000. p. 1-26.

6. Yaldiz O, Ozturk H, Zeren $\mathrm{H}$, et al. Energy usage in production of field crops in Turkey. 5th International Congress., Kusadasi, Turkey: On Mechanization and Energy Use in Agricultur; 1993. p. 11-14.

7. Singh S, Singh G. Energy input vs. crop yield relationship for four major crops of northern India. Agricultural Mechanization in Asia, Africa and Latin America. 1992;23(2):57-61.

8. Anonymous. Iran agriculture statistics. Department of statistics and information, Ministry of Jihad-e-Agriculture, Tehran, Iran; 2011.

9. Yousefi M, Mahdavi DA, Khoshbakht K, et al. Renewable and nonrenewable energy use pattern of rainfed wheat agroecosystems in Iran. World Appl Sci J. 2011;13(6):1398-1403.

10. Yousefi M, Mohammadi A. Economical analysis and Energy use efficiency in Alfalfa production systems in Iran. Scientific Research and Essays. 2011;6(11):2332-2336. 
11. Yousefi M, Mahdavi DA, Khoramivafa M. Energy consumption, greenhouse gas lemissions and assessment of sustainability index in corn agroecosystems of Iran. Sci Total Environ. 2014;493:330-335.
12. Yousefi M, Khoramivafa M, Mondani F. Integrated evaluation of Energy use, Treenhouse gas emissions and Global warming potential for sugar beet (Beta vulgaris) lagroecosystems in Iran!. Atmospheric Environment. 2014;92:501-505. 